\title{
IAMJ
}

INTERNATIONAL

AYURVEDIC

MEDICAL JOURNAL

Review Article

ISSN: 2320-5091

Impact Factor: 6.719

\section{EVALUATION OF HISTOLOGICAL CONCEPT IN AYURVEDA}

\section{$\underline{\text { Doley Lakhiprova }}^{1}$, Soni Gaurav ${ }^{2}$}

${ }^{1,2}$ Lecturer, Department of Rachana Sharir, North Eastern Institute of Ayurveda \&Homeopathy, Shillong, Meghalaya-793018., India

Corresponding Author: doley.lakhiprova@gmail.com

\section{https://doi.org/10.46607/iamj3209092021}

(Published Online: September 2021)

Open Access

(c) International Ayurvedic Medical Journal, India 2021

Article Received: 20/08//2021 - Peer Reviewed: 02/09/2021 - Accepted for Publication: 03/09/2021

\section{Check for updates}

\begin{abstract}
Histology is the science where microanatomy of cells and tissues are studied, including their role in the body, and the way they are affected by disease. They are the basic elements and building blocks of everything in the body. Therefore, a thorough knowledge of normal histology is very important for the understanding of the normal functioning of the human body. It also forms the essential basis for the study of the changes in various tissues and organs in disease conditions. In Ayurveda, the micro-anatomical concept can be emphasized under the heading of Paramanu, which can be further elaborated in other different anato-physiological concepts like - Dosha, Dhatu, Upadhatu, Kala in a broad aspect. Srota also in its functional aspect highlights the histological concept. Among all these, Kala and Dhatu specifically indicate the different limiting membrane and tissue of the body. Bhagavata emphasized the Kala as fibrous, serous, or mucosal structures of the body. Therefore, it is necessary to ascertain and re-establish nearest histological concept available in different classics emphasizing on the modern platform for better understanding and implementation of novel innovation.
\end{abstract}

Keywords: Kala, Dhatu, Epithelial tissue, Muscle tissue, Haemopoetic tissue. 


\section{INTRODUCTION}

Histology is the study of tissues of the body and deals with the minute structures of the body. So, it is a structural science. The cell is the smallest structural unit possessing those properties which are commonly associated with life. From this smallest unit, the specialized tissues of the body are formed. In Ayurveda, the concept of the microstructures of the body can be studied under the heading of Paramanu, Dosha, Dhatu, Upadhatu, Kala, Srota, Srotamsi in a broad aspect. References are available regarding Kala and dhatu in whole classical books, where they indicate the different tissue and limiting membrane of the body. Kala is the thin membrane that lines the internal cavity of the ashayas, organs, blood vessels and they separate the dhatu and ashayas. It is also mentioned that they are like jarayu which is covered by kaphadosha. Vagbhatas concept of Kala sometimes indicates fibrous, serous or mucosal structures of the body. In classics, seven types of kalas are mentioned which are mamsadharakala, medadharakala, purishadharakala, sukradharakala, raktadharakala, shlesmadharakala and pittadharakala. Similarly seven numbers of dhatu are mentioned almost in all classics which are rasa, rakta, mamsa, meda, asthi, majja and sukradhatu. The present study wants to emphasize specifically the concept of Kala and Dhatu about different histological aspects along with functional aspects as mentioned in classics.

\section{AIM}

1. Review of concept of Kala and dhatu.

2. Analysis of histological concept in Ayurveda in terms of Kala and dhatu.

\section{MATERIAL AND METHODS:}

1. The present study is designed to evaluate the fundamental entities namely Kala and Dhatu from available classical references. Respective commentaries will be analyzed in these contexts.

2. The structure will be analyzed from the histological point of view in relation with following types of tissues - epithelial tissue, connective tissue, muscle tissue, nervous tissue etc.

\section{DISCUSSION}

In Ayurveda, the histological concept can be studied under the heading of Kala and saptadhatu in specific. Kala can be understood as epithelial lining present in different parts of the body as well as the mucus, serous and fibrous membranes present in the body. ${ }^{1,2}$ The term Dhatu highlights all the basic elements which render three main functions viz. nutrition, sustenance and growth in general while in specific it can be emphasized under saptadhatu viz. Rasa, Rakta, mamsa, meda, asthi, majja and sukra, indicate different tissues of the body. They impart structural architecture. ${ }^{3}$ Rasa dhatu can be understood as interstitial fluid and lymph in general while plasma is specific. Basic function i.e., prinana means nourishment, which supplies to different tissues of the body. ${ }^{4} \mathrm{Rak}$ tadhatu can be correlated along with blood tissue. It is said that when the rasa circulates through raktasthana, gets coloured by usma of ranjak pitta, then it is known as rakta. It is bright red like gunjaphala and gives nourishment, complexion to the body and maintains life. It is vital for the existence of life. ${ }^{5,6}$ Mamsadhatu can be understood along with muscle tissue. Peshi formed by the divisions of mamsa which mainly acts as covering of internal organs and protects them. It strengthens and joins by covering them through tendons or ligaments. ${ }^{7,8}$ Medadhatu is mainly present in the abdomen in vapabahana(omentum) as well as in diaphysis of the small bone. It gives strength to the body, produces lubrication and moist the skin. All these highlight the similar characteristics of adipose tissue. ${ }^{9}$ Asthidhatu mostly indicate osseous tissue in specific while it also indicates cartilaginous tissue in general. Both bone and cartilage form the skeletal framework and support the body which is mentioned as a function of asthi. ${ }^{10,11,12}$ Majjadhatu performs the functions of asthipurana, which indicates bone marrow. ${ }^{13,14}$ Sukradhatu present in both male and female, bears functions of hypothalamopituitary axis in general, while its function of garbhautpadana indicates semen in male. ${ }^{15}$ Kala is the limiting lining between the Dhatuand Asaya, 
which is mentioned as "snaysleshmajarayuschanna" i.e fibrous, serous and mucous in nature. ${ }^{1 .}$ Thus, the mamsadharakala can be understood along with intermuscular septum and epimysium, perimysium, endomysium, which are covering of a muscle, fasciculi and individual muscle fibre respectively. Three terminologies namely bisamrinala exhibit ramification of veins, pankaudaka can be identified with specific muscle, while bhumi can be considered as lamina of muscle tissue. ${ }^{16,17}$ Raktadhara kala is present inside the mamsa which contains blood, present in sira, yakrit and pleeh. This can be understood in modern parlance as the endothelial lining of the blood vessels, capillaries and sinusoids in the liver and spleen where they act as the reservoir of blood. ${ }^{18}$ Medodhara kala resembles a fat depot of peritoneum i.e. omentum and fatty layers of superficial fascia. The diaphysis indicates other deposition of sarakta meda. ${ }^{19}$ Sleshmadhara kala is present specifically in synovial joints and contains synovial fluid. Hence it can be understood with synovial membrane. ${ }^{20}$ Purishadhara kala found in pakwasaya, responsible for sarakittavibhajan. It is present in the antrani situated in yakritsamantata extending from unduka. Therefore it indicates mucosal lining of the large intestine in- cluding ceacum which is a specific place for absorption of water, salt and other solute materials. ${ }^{21}$ Pittadhara kala specially can be understood as epithelial lining as well as a submucous layer of the small intestine where various glands like Brunner's gland, Crypt of Lieberkuhn are present and responsible for digestion absorption which can be understood along with functions of pitta present in it. ${ }^{22}$ Sukradhara kala in general represents the entire hypothalamo-pituitary axis responsible for maintaining specific functions. However, from the aspect of the specific function of sukradhatu i.e. garbhadhana, it is better to correlate with seminiferous tubule as well as epithelial lining of the male reproductive organ. ${ }^{23}$ Dhatu when studied from the view of histology can be understood with different types of tissue described in modern histology. When tissues are studied specifically from their functional aspect, they can be understood with different aspects of dhatu in general while in specific along with saptadhatu. In all classics, the kalas are described as limiting layers of the body organs and tissues, which highlight the epithelial lining and other membrane-like mucus, serous and fibrous layers present in different parts of the body and bear protective, secreting, excreting and absorbing functions.

Table 1- Correlation of different tissues along with their functional aspects

\begin{tabular}{|c|c|c|c|}
\hline Tissue & Function & Correlation & Function \\
\hline Epithelial tissue & $\begin{array}{l}\text { Supporting sheet, Protec- } \\
\text { tive, Secretion, Digestion, } \\
\text { Absorption, Separation, } \\
\text { Excretion }\end{array}$ & $\begin{array}{l}\text { Different Kala of the body viz. } \\
\text { mamsadhara, raktadhara, } \\
\text { medodhara, sleshmadhara, } \\
\text { purisadhara, pittadhara, suk- } \\
\text { radhara }\end{array}$ & $\begin{array}{l}>\text { Present between Dhatwa- } \\
\text { sayaantarmaryada. } \\
>\text { Dharana, paka, paripaka, } \\
\text { parinama. }\end{array}$ \\
\hline $\begin{array}{l}\text { Plasma (in spe- } \\
\text { cific) }\end{array}$ & $\begin{array}{l}\text { Carries nourishment to tis- } \\
\text { sue, acts as the main com- } \\
\text { ponent of circulation. }\end{array}$ & Rasa dhatu & $\begin{array}{ll}> & \text { Prinana } \\
> & \text { raktapusti }\end{array}$ \\
\hline $\begin{array}{l}\text { Blood (specifi- } \\
\text { cally cellular } \\
\text { components) }\end{array}$ & $\begin{array}{l}\text { Provides nourishment to the } \\
\text { body by oxygen circulation, } \\
\text { carries away carbon diox- } \\
\text { ide, imparts complexion to } \\
\text { body }\end{array}$ & Raktadhatu & $\begin{array}{l}\text { Jivana, Barnaprashada, } \\
\text { nourishes specific tissue i.e. } \\
\text { muscle tissue. }\end{array}$ \\
\hline Bone tissue & $\begin{array}{l}\text { Forms skeletal framework } \\
\text { hence gives shape, carries } \\
\text { weight. }\end{array}$ & Asthidhatu & $>$ Dehadharana \\
\hline
\end{tabular}




\begin{tabular}{|c|c|c|c|}
\hline Bone marrow & $\begin{array}{l}\text { Fills the medullary cavity, } \\
\text { Storage of fats. }\end{array}$ & Majja & $>$ Purana, \\
\hline Muscle tissue & & MamsaDhatu & $>\quad$ lepana, sarirapusti \\
\hline Nervous tissue & & $\begin{array}{l}\text { Vatavahisira, Nadi, Sometime } \\
\text { snayu also comes under this. }\end{array}$ & \\
\hline $\begin{array}{l}\text { Reproductive } \\
\text { tissue }\end{array}$ & Responsible for genesis. & SukraDhatu & $>$ garbhautpadana. \\
\hline
\end{tabular}

\section{CONCLUSION}

In histology, tissue is classified based on their functions which draw attention to the striking resemblance with saptadhatu described in Ayurveda. Thus, according to modern view, plasma and formed elements are together treated as single, on the other hand in Ayurveda Rasa and Raktadhatu are each sthayidhatu. Likewise adipose tissue, osseous tissue is included under one category i.e., the connective tissue in modern science while in Ayurveda they are two distinct and different dhatu which have their own identity and functions. In addition, the majjadhatu is the Ayurvedic analogue of bone marrow has been treated as distinct and different from medodhatu, even though according to modern views, both represent fat tissue. The definition of the term Kala and its functions described in classics resemble most of the protective or epithelial tissue along with different membranes. The study revealed, mamsadhara kala indicate intermuscular septum and epimysium, perimysium, endomysium, which are covering of a muscle, fasciculi, and individual muscle fibre respectively. The pittadhara and purishadhara kalas are suggestive of the covering membrane of the small and large intestine, where various glands like Brunner's gland, Crypt of Lieberkuhn are present in the small intestine which are concerned with digestion, assimilation and absorption. Here it renders the functions of pitta i.e. paka, paripaka and parinama. Thus, raktadharakala when studied together with the endothelial lining of blood vessels and capillaries, sinusoid of liver, spleen and bone, and medodhara kala especially that of majja, present a striking conceptual resemblance to the epithelial tissue. Therefore, it is concluded that kalas can be seen as similar to different membranes of the body. Apart from these two i.e. dhatu and kala, the concept of upadhatu also can be highlighted under histological aspect in Ayurveda.

\section{REFERENCES}

1. Ghanekar B.G, Susrutsamhita, MeharchandLashmandas publication, New Delhi, sarirasthana 4/4, p-108.

2. Sarma P.V, Astangasamgraha, chaukhambhaOrientalia, Varanasi, Sarirsthana 5/32, p-102.

3. Sarma P.V, Susrutsamhita, chaukhambhaOrientalia, Varanasi, sutra sthana 14/20, p-104.

4. Sarma P.V, Susrutsamhita, chaukhambhaOrientalia, Varanasi, sutra sthana 15/7, p-115.

5. Sarma P.V, Susrutsamhita, chaukhambhaOrientalia, Varanasi, sutrasthana 14/4-5, p-100.

6. Sarma P.V, Carakasamhita, chaukhambhaOrientalia, Varanasi, cikitsha sthana 15/28.

7. Sarma P.V, AstangaHridaya, chaukhambhaOrientalia, Varanasi, Sutra sthana 14/4.

8. Ghanekar B.G, Susrutsamhita, MeharchandLashmandas publication, New Delhi, sarirasthana 5/49.

9. Sarma P.V, Susrutsamhita, chaukhambhaOrientalia, Varanasi, sutra sthana 15/7, p-115.

10. Sarma P.V, Susrutsamhita, chaukhambhaOrientalia, Varanasi, sutra sthana 15/7, p-115.

11. Ghanekar B.G, Susrutsamhita, MeharchandLashmandas publication, New Delhi, sarirasthana 5/23-25, p163.

12. Prof. K.R. Srikantha Murthy, Sarangadharsamhita, Chaukhambha Orientalia, Varanasi, edition2016, purvakhanda,5/37.

13. Sarma P.V, Susrutsamhita, chaukhambhaOrientalia, Varanasi, sutra sthana 15/7, p-115

14. Sarma P.V, AstangaHridaya, chaukhambhaOrientalia, Varanasi, Sutra sthana, 11/4.

15. Ghanekar B.G, Susrutsamhita, MeharchandLashmandas publication, New Delhi, sarirasthana 4/19.

16. Sarma P.V, AstangaSamgraha, chaukhambhaOrientalia, Varanasi, Sarirasthana, 5/33, p-102 
17. Ghanekar B.G, Susrutsamhita, MeharchandLashmandas publication, New Delhi, sarirasthana 4/7, p-108.

18. Ghanekar B.G, Susrutsamhita, MeharchandLashmandas publication, New Delhi, sarirasthana 4/9, p-109. Sarma P.V, AstangaSamgraha, chaukhambhaOrientalia, Varanasi, Sarirasthana 5/34, p-103.

19. Ghanekar B.G, Susrutsamhita, MeharchandLashmandas publication, New Delhi, sarirasthana 4/11, p-109. Sarma P.V, AstangaSamgraha, chaukhambhaOrientalia, Varanasi, Sarirasthana 5/35, p-103.

20. Ghanekar B.G, Susrutsamhita, MeharchandLashmandas publication, New Delhi, sarirasthana 4/13, p-110. Sarma P.V, AstangaSamgraha, chaukhambhaOrientalia, Varanasi, Sarirasthana 5/36, p-103.

21. Ghanekar B.G, Susrutsamhita, MeharchandLashmandas publication, New Delhi, sarirasthana 4/15, p-110. Sarma P.V, AstangaSamgraha, chaukhambhaOrientalia, Varanasi, Sarirasthana 5/37, p-104.

22. Ghanekar B.G, Susrutsamhita, MeharchandLashmandas publication, New Delhi, sarirasthana 4/17, p-111. Sarma P.V, AstangaSamgraha, chaukhambhaOrientalia, Varanasi, Sarirasthana 5/38, p-104.

23. Ghanekar B.G, Susrutsamhita, MeharchandLashmandas publication, New Delhi, sarirasthana 4/19, p-111. Sarma P.V, AstangaSamgraha, chaukhambhaOrientalia, Varanasi, Sarirasthana 5/39, p-104.

24. Inderbir Singh, Textbook of Human Histology, sixth edition.

\section{Source of Support: Nil \\ Conflict of Interest: None Declared}

How to cite this URL: Doley Lakhiprova \& Soni Gaurav: Evaluation Of Histological Concept In Ayurveda. International Ayurvedic Medical Journal \{online\} 2021 \{cited September 2021\} Available from: http://www.iamj.in/posts/images/upload/2135_2139.pdf 